\title{
Correction to: The Impact of Immunodeficiency on NK Cell Maturation and Function
}

\author{
Alexander Vargas-Hernández ${ }^{1,2} \cdot$ Lisa R. Forbes ${ }^{1,2}$
}

Published online: 7 March 2019

(C) Springer Science+Business Media, LLC, part of Springer Nature 2019

\section{Correction to: Current Allergy and Asthma Reports (2019)19:2 \\ https://doi.org/10.1007/s11882-019-0836-8}

The section heading that reads PI3K1008 deficiency should be corrected to read PI3K1108 deficiency.

Publisher's Note Springer Nature remains neutral with regard to jurisdictional claims in published maps and institutional affiliations.

The online version of the original article can be found at https://oi.org/ $10.1007 / \mathrm{s} 11882-019-0836-8$

Lisa R. Forbes

lisa.forbes@bcm.edu

1 Department of Pediatrics, Immunology Allergy and Rheumatology, Baylor College of Medicine, Houston, TX, USA

2 Center for Human Immunobiology, William T Shearer Center for Human Immunobiology, Texas Children's Hospital, 1102 Bates Ave, Suite 330, Houston, TX 77030, USA 